\title{
Evaluation of Neoproterozoic Source Rock Potential in SE Pakistan and Adjacent Bikaner- Nagaur Basin India Based on Integrated Geochemical, Geological, and Geophysical Data
}

\section{Qamar Yasin}

China University of Petroleum (East China)

\section{Syrine Baklouti}

National School of Engineers of Sfax

Ghulam Mohyuddin Sohail

University of Saskatchewan

Muhammad Asif

ExxonMobil Upstream Research Company

Gong Xufei ( $\nabla$ gongxufei@sdust.edu.cn )

Shandong University of Science and Technology

\section{Research Article}

Keywords: Neoproterozoic rocks, Rock-Eval pyrolysis, biomarkers, surface geochemical survey, BikanerNagaur Basin India, Indus Basin Pakistan

Posted Date: December 2nd, 2021

DOI: https://doi.org/10.21203/rs.3.rs-1099958/v1

License: (c) (i) This work is licensed under a Creative Commons Attribution 4.0 International License.

Read Full License 


\section{Abstract}

Discoveries of heavy crude oil in the Neoproterozoic rocks (Infracambrian rock sequence) from the Bikaner-Nagaur Basin of India emphasizes the significance to study and explore the Neoproterozoic source rocks potential in the southeastern part of Pakistan. This study evaluates the potential of the source rock in the Infracambrian rock sequence (Salt Range Formation) based on surface geochemical surveys, Rock-Eval pyrolysis, source biomarkers, geophysical characterization, and seismic inversion using machine learning for maturity index estimation. Core samples of Infracambrian rock were extracted for Rock-Eval pyrolysis and biomarker characterization. Also, 81 geo-microbial soil and gas samples were collected from the surface to explore the petroleum system and potential source rocks in the subsurface. We followed the standard laboratory procedures to investigate the origin and concentration of hydrocarbons gases at the surface, thermal maturity, the source facies, and the environment of deposition of organic matter. The results show that the investigated samples are characterized by restricted marine clay devoid of carbonate source facies with thermal maturity in the early-stage of the oil generation window. Surface geochemical samples also confirm higher concentrations of thermogenic C2C4 hydrocarbons over the vicinity of anticlinal structures proving the existence of an effective migration path along deep-seated faults to the surface. The inverted maturity index profile demonstrates a reasonable correlation of thermal maturity with the surface geochemical survey, source biomarkers, and Rock-Eval pyrolysis. It validates the reliability of multilayer linear calculator and particle swarm optimization algorithms for inverting seismic reflection data into a maturity index profile. The obtained results indicate a higher probability of heavy and light oil along the eastern flank of Pakistan, where Infracambrian rocks are thicker and more thermally mature, and deep-seated pledged structural closures occur, in comparison to the Bikaner-Nagaur Basin, India.

\section{Introduction}

Neoproterozoic rocks are among the oldest rock units in the world, and several successful discoveries have been reported from these sequences in Salt Basins of Oman and Siberia ${ }^{1-5}$. In the Bikaner-Nagaur (BK-N) Basin India, 935 million barrels of heavy oil reserves have been discovered in the Infracambrian Jodhpur sandstone, the Bilara dolostone, and the thin siltstone layers in the Hanseran evaporite which the porosity ranges between $16-25 \%, 7-15 \%$, and $3-12 \%$, respectively 5,6 . The heavy oil discovered is nonbiodegraded, and biomarker ratios support crude oil from the source rock in the early-stage of oil generation 2,7,8. In the BK-N Basin, the biomarker study from the Baghewala-1 well reveals that mature hydrocarbons have been generated from a deeper buried source rock ${ }^{2}$. Several authors reported that the same quantities of petroleum could be generated from the Infracambrian source rock of Salt Range (SR) Formation in southeastern (SE) Pakistan, where Infracambrian source rock beds are much deeper and thicker than that in the BK-N Basin 2,6,9.

In recent years, the Infracambrian play in SE Pakistan has been explored to assess the hydrocarbon potential by geological modelling or seismic data characterization ${ }^{6,9-12}$. However, the previous attempts 
focused only on the distribution of Infracambrian source and reservoir rocks in SE Pakistan, but no study has directly investigated the potential and maturity of Infracambrian source rocks. In this paper, we evaluate the distribution and potential of Infracambrian source rocks based on the combination of surface geochemical prospecting, biomarkers parameters, geophysical characterization, and seismic inversion using supervised machine learning algorithms, i.e., particle swarm optimization (PSO) and multilayer linear calculator (MLC) to transform the seismic sections into maturity index (MI) profile. This is the first time we have investigated the area utilizing a combination of all of these techniques.

Furthermore, we correlated the origin of surface geomicrobial gases with gravity modelling and seismic data interpretation. Also, the stratigraphic succession of the study area was compared with the BK-N Basin to understand the Infracambrian stratigraphic variation, thickness of sediments, burial depth of source rocks, and play concept.

\section{Regional Geological Setting And Stratigraphy 2.1. Geological setting}

The study area is located in the eastern segment of the central region of the lower Indus Basin that is divided, west to east, into broad tectonic divisions the Punjab Platform in SE Pakistan, the Suleiman Ranges that is composed of depression and fold belts, and the BK-N Basin in NW India that is bounded by the Sargodha High to the north and the Pokaran High to the south (Figs. 1a and 1b). The entire area is covered by Quaternary alluvium that westward extends along with the Suleiman Depression and Fold Belts ${ }^{13,14}$. In SE Pakistan, the Punjab Platform covers about $58,000 \mathrm{~km}^{2}$ and extends the BK-N Basin eastwards in Rajasthan, India (Fig. 1a). Seven exploratory wells have been drilled in the CambrianPrecambrian rocks in SE Pakistan, which heavy oil was observed in the SR Formation from the Karampur1 well (Fig. 1b). The heavy oil shows geochemically resembled the heavy oil from the Baghewala-1 well in the BK-N Basin ${ }^{2}$. Similar geochemistry of heavy oil has been reported from carbonate-evaporite facies of the Huqf Group (Infracambrian), located at more than $2000 \mathrm{~km}$ to the SW, along the eastern flank of southern Oman 2,6,10,12. At the scale of the regional geology, these Infracambrian rocks were once within or near the western edge of Gondwanaland that was marked by a subsiding rift system, present-day outcropping to the west of the Aravalli ranges in the BK-N Basin and extending toward the north and northwest Pakistan ${ }^{1,2,9}$. The exposures of the Aravalli Range in the northwestern Indian Shield allowed the development of sedimentary basins along its flanks (Fig. 1b). The movement of the tectonic plates is responsible for the Precambrian rocks' deformation and causes several subsided and uplifted blocks. This tectonic subsidence, resulting in the BK-N Basin development, which can be tied in with KiranaTosham Basin ${ }^{9}$. The local Highs that existed in the study area are inferred from Early Infracambrian times that frame the basin configuration more complicated. The seismic data show a reversal bedding in the deposition of sediments that could be interpreted as Paleozoic and Mesozoic non-orogenic movements in the central region of the Indus Basin ${ }^{10,14}$. The bedding is dominantly oriented to the west. Thus, it is assumed that the Neoproterozoic deposition was primarily controlled by horst and graben structure and topography, possibly accompanied by the breakup of Pannotia. 
The Infracambrian SR Formation is exposed in the northeastern part of Pakistan (Potwar Plateau) ${ }^{9,10}$. Exposures of Precambrian rocks occur as many hillocks (volcanic and volcaniclastics) located at Kirana Hills (Hachi volcanic) in the Sargodha-Shahkot-Sangla-Chiniot region of SE Pakistan ${ }^{15,16}$. These Hachi volcanic are analogous to Infracambrian rocks in the Nagar Parkar (Tosham-Malani volcanic India), as these crystalline rocks, with or without the cover of Phanerozoic, lie at the bottom of the Indus Basin ${ }^{9}$.

\subsection{Lithostratigraphy}

The lithostratigraphy of the study area was investigated using outcrops and the well logs data from BK-N Basin India and SE Pakistan. The lithostratigraphy of the BK-N Basin is dominantly composed of nearly $1,000 \mathrm{~m}$ of shales, sandstones, carbonates, and evaporates. This lithology is quite similar to the Potwar sub-basin (upper Indus Basin) ${ }^{6,10}$. Several regional unconformities, erosion, and hiatuses were observed in the study area through the sedimentary succession. The Infracambrian Salt Range (SR) Formation unconformably overlies a Precambrian basement ${ }^{18}$. Another erosional unconformity surface is observed between the Early-Middle Cambrian SR Formation and the Middle/Upper Permian Tobra Formation (Fig. 2). This widespread Early-Middle Cambrian and the Middle/Upper Permian unconformity occurred due to localized uplift and a global eustatic fall in sea level. The upper part of the SR Formation is sometimes absent due to erosion during the Cambrian and Permian unconformity. The maximum thickness of the SR Formation is $906 \mathrm{~m}$.

The Permian rocks are covered by about $400 \mathrm{~m}$ of thick marine Cenozoic sediments, gradually thickening westward. The Paleocene-Eocene succession comprises foraminiferal sandstone, limestone, and shale. It is overlain by Neogene fluvial clastic consisting of thick alluvium silt, sand, and clay layers ${ }^{13}$. Fig. 2 shows a generalized stratigraphic column based on data from the Karampur-1 well.

Four stratigraphic units of the SR Formation are identified in the study area that are equivalent to the Infracambrian rocks in the BK-N Basin. The lithostratigraphy of the SR Formation is based on the depositional environment and lithological log information from Suji-1, Marot-1, Karampur-1, and Bahawalpur East-1 wells ${ }^{10,15,19}$. The SR Formation is subdivided, from oldest to youngest, into four formations: Sonia, Jodhpur, Bilara, and Hanseran (Fig. 3). The Hachi volcanic (equivalent to Tosham Malani igneous suite) forms the basement. Both Hachi and Tosham Malani volcanic unconformably underlie the Basal conglomerates, composed of dolomites and volcano-clastic. The clastic sediments of the Jodhpur Formation form the primary potential reservoir in the basin and can be classified into Sonia shale and sandstone members. The Bilara-Hanseran sequence lies conformably over the Jodhpur Formation. The Bilara-Hanseran acts as a source rock with TOC ranges from 5 to $6 \%{ }^{20}$. The calcareous Bilara Group comprises dolomite, limestone, stromatolitic limestone, and occasional clay beds. The Hanseran Evaporite Group comprises mainly of halite, anhydrite, dolomite, and reddish sandstone with

thin shale beds. The Bilara-Hanseran sequence has total estimated thickness of about $200 \mathrm{~m}^{20}$. The comparison of Infracambrian and Cambrian succession between the BK-N Basin and SE Pakistan is described in Table 1. 
Table 1

Maximum thickness and petroleum system of the Cambrian-Infracambrian succession in the SE Pakistan and BK-N Basin.

\begin{tabular}{|c|c|c|c|c|c|}
\hline Age & $\begin{array}{l}\text { BK-N } \\
\text { Basin } \\
\text { India }\end{array}$ & $\begin{array}{l}\text { Thickness } \\
\text { (m) }\end{array}$ & SE Pakistan & $\begin{array}{l}\text { Thickness } \\
(\mathrm{m})\end{array}$ & $\begin{array}{l}\text { Petroleum } \\
\text { system }\end{array}$ \\
\hline \multirow[t]{3}{*}{ Cambrian } & \multirow{2}{*}{$\begin{array}{l}\text { Upper } \\
\text { Carbonate }\end{array}$} & 230 & Jutana Dolomite & $12-112$ & \\
\hline & & \multirow[t]{2}{*}{180} & Kussak Formation & $93-217$ & \\
\hline & Formation & & Khewra Sandstone & $101-152$ & \\
\hline \multirow[t]{4}{*}{ Infracambrian } & \multirow{2}{*}{$\begin{array}{l}\text { Hanseran } \\
\text { Evaporite }\end{array}$} & \multirow{2}{*}{$\begin{array}{l}170 \\
40\end{array}$} & \multirow{2}{*}{$\begin{array}{l}\text { salt, marl, gypsum, and } \\
\text { dolomite (SR Formation) }\end{array}$} & $140-1143$ & \multirow{3}{*}{$\begin{array}{l}\text { Source, } \\
\text { reservoir, } \\
\text { seal, } \\
\text { Source }\end{array}$} \\
\hline & & & & 2300 & \\
\hline & $\begin{array}{l}\text { Bilara } \\
\text { Dolomite }\end{array}$ & \multirow[t]{2}{*}{50} & $\begin{array}{l}\text { conglomerate, shale } \\
\text { (Sharaban Formation) }\end{array}$ & & \\
\hline & $\begin{array}{l}\text { Jodhpur } \\
\text { Formation }\end{array}$ & & $\begin{array}{l}\text { Hadda Quartzite, quartzite } \\
\text { (Asianwala Formation), } \\
\text { phyllite (Taguwali } \\
\text { Formation) }\end{array}$ & & Reservoir \\
\hline \multirow[t]{4}{*}{ Precambrian } & \multirow{2}{*}{$\begin{array}{l}\text { Volcanic } \\
\text { rocks }\end{array}$} & \multirow[t]{4}{*}{+150} & Hachi Volcanics & & \\
\hline & & & \multirow[t]{3}{*}{ Basement } & & \\
\hline & Basement & & & & \\
\hline & $\begin{array}{l}\text { (Malani } \\
\text { Suite) }\end{array}$ & & & & \\
\hline
\end{tabular}

\subsection{Structural style}

The regional schematic section of structural interpretation from the basement to the Eocene based on cross-section across the wells; Ahmedpur-1, Bahawalpur-1, Marot-1, Fort Abbas-1, Suji-1, Bijnot-1, and Baghewala-1, in the SE Pakistan and BK-N Basin India is shown in Fig. 4. The correlation of these exploratory wells identifies the Infracambrian rock sequence (SR Formation) at a depth varying from 1100 to $2600 \mathrm{~m}$ (east to the west) and highlights several unconformities in the stratigraphic succession. From the figure, we observe that the Miocene, Paleocene, Permian, and Cambrian sediments gradually thin toward the east, contrasting with the Infracambrian sediments. The lithological log correlation results classify the Infracambrian rock into four lithofacies, i.e., shale, sandstone, dolomite, and evaporates ${ }^{21}$.

The basement rocks in the Karampur-1, Marot-1, Fort Abbas-1, Suji-1, Bijnot-1, and Baghewala-1 (India) wells are composed of rhyolite, weathered tuff, ash, and brittle clay with interbedded flows of basalt and trachyte. At about $1000 \mathrm{Ma}$, mantle plume and rifting initiated by Infracambrian time generated widespread igneous activity during the post-Aravalli period. This wide variation in volcanic activity suggests extensional tectonics followed by deposition in the BK-N and Indus Basins.

Figure 5 shows the Infracambrian play concept in Kirana-Malani-Tsham Basin ${ }^{6}$. From rifting to collision and underthrusting of the Indian Plate during Infracambrian to Mesozoic, the basin is associated with 
deep-seated normal faults, salt-induced structures, horst and graben structural highs and lows. The previous drilling campaign in the BK-N Basin revealed that wells located on paleo-highs did not encounter Infracambrian strata than those drilled on paleo-lows ${ }^{9}$.

\section{Materials And Methods 3.1. Data description}

Logs and core data, including well-cuttings from nine wells, as shown in Table 2, were used for estimating the total organic carbon (TOC), rock-eval pyrolysis, biomarkers, mineralogy, saturation, porosity, and permeability in the Infracambrian to Permian rocks. Also, surface geo-microbial soil and gas samples were investigated to evaluate the petroleum potential of source rocks in the subsurface. Moreover, 1000 $\mathrm{km}$-long 2D seismic data were interpreted to mark the stratigraphic horizons and structural style, focusing mainly on the top and bottom reflectors of the Infracambrian-Cambrian rocks.

Table 2

Summary of the exploratory wells drilled through the Infracambrian to Permian play in the SE Pakistan and BK-N Basin India.

\begin{tabular}{|llllll|}
\hline Exploratory well & Time & $\begin{array}{l}\text { Depth } \\
(\mathbf{m})\end{array}$ & $\begin{array}{l}\text { Drilled } \\
\text { upto }\end{array}$ & $\begin{array}{l}\text { Target } \\
\text { Reservoir }\end{array}$ & Comments \\
\hline Karampur-1 & 1959 & 3034 & Basement & Base Permian & Heavy asphaltic oil \\
\hline Bahawalpur East-1 & 1980 & 3024 & Basement & Base Permian & Gas shows \\
\hline Marot-1 & 1981 & 2596 & Basement & Base Permian & Fluorescence \\
\hline Baghewala-1 (India) & 1991 & 1570 & Basement & Infracambrian & Oil discovery \\
\hline Pugal-1 & 1991 & 0678 & Precambrian & Infracambrian & Heavy oil \\
\hline Fort Abbas-1 & 1994 & 1651 & Precambrian & Base Permian & Abandoned \\
\hline Bijnot-1 & 1996 & 1914 & Basement & Infracambrian & Good oil shows \\
\hline Suji-1 & 2000 & 2628 & Basement & Infracambrian & Low maturity \\
\hline Maharvi-1 & 2007 & 2980 & Basement & Infracambrian & Low maturity \\
\hline
\end{tabular}

\subsection{Methods}

The following sequence was adopted to achieve the study's objectives. 


\subsubsection{Surface geochemical survey}

Surface geo-microbial soil and soil gases were studied to explore the prospective areas of hydrocarbon microseepage and its origin. For this purpose, we collected 81 soil and gas samples along seismic lines over the study area, as shown in Fig. 6. The samples were extracted from varying depths, 0.8 to $1.5 \mathrm{~m}$ using a soil sampler, mechanical auger, sterilized soil sampling bags, and vacuum gas sampling bags. To suck up the gas, a syringe was injected into the septum after sealing the annulus between the sampling tube and the borehole, as described by Tedesco ${ }^{22}$. While the area of interest is situated among arid climate zone, all necessary measures were taken into consideration during sampling, e.g., avoid sampling the soils from water-saturated as well as excavated areas, land contaminated by hydrocarbons, animal feces, the flow of chemicals, marshes, and the areas under water table ${ }^{23}$.

We incubate soil samples with light hydrocarbon gases in the mineral salt medium for geo-microbial analysis and count the hydrocarbon oxidizing bacteria that have developed. For gas analysis, hydrocarbon gases desorbed from soil samples through acid-base extraction were analyzed by gas chromatography. The results were shown using concentration distribution maps to identify areas with anomalously high concentrations. Anomalies were marked through a statistical analysis approach, where the mean plus half standard deviation was assumed as the background value.

\subsubsection{Rock-Eval pyrolysis}

Rock-Eval pyrolysis was used to identify the maturity of $\mathrm{OM}$ and generative potential of the Infracambrian rock. Four basic parameters, such as oxygen index $(\mathrm{OI})$, production index $(\mathrm{PI})$, hydrogen index $(\mathrm{HI})$, and maximum temperature (Tmax), were obtained by pyrolysis. The chosen samples were measured using Vinci Rock-Eval 6 apparatus by following the previously reported procedures ${ }^{24-26}$. Approximately ten well cuttings samples from the Bijnot- 1 were investigated to measure the OI, HI, PI, Tmax, and TOC. LECO's CS230-series carbon and sulfur determinator was used to measure the TOC content of well cuttings samples by following the formal standards process (CNS GB/T19145-2003).

\subsubsection{Biomarkers analysis}

The ten well-cuttings samples were also extracted for sedimentary OM characterization. Extracts were separated by liquid chromatography into aliphatic and aromatic fractions of hydrocarbons and further analyzed by gas chromatography-mass spectrometry (GC-MS). Both aliphatic and aromatic biomarkers were analyzed to evaluate the organic matter's source facies, thermal maturity, and deposition environment. The methods, techniques, and guidelines are similar to those reported in the literature $27-29$.

\subsubsection{Maturity index (MI) calculation}

Zhao et al. ${ }^{30}$ developed a relationship between $\mathrm{Ml}$ and Tmax to determine the kerogen type. They established two baselines, i.e., $\mathrm{Ml}<5$ referring to the oil with some dissolved gases and $\mathrm{MI}>7$ indicating 
dry gases without any condensate. The values of MI between 5 and 6 indicate oil (or condensate) and wet gas.

Bulk density, neutron porosity, shear and compressional sonic, and deep resistivity logs, which are sensitive to maturity variations, were utilized in Bijnot- 1 well to compute the $\mathrm{MI}$ in the Infracambrian rock by employing Equ. (1). In this equation, Zhao et al. ${ }^{30}$ evaluated the total and effective porosities of the formation from the core samples and correlated it with porosity calculated from the density log in the same interval in order to determine the threshold values of MI.

In this study, data of samples with log density porosity greater than $9 \%$ with water saturation less than $75 \%$ were included in the calculations of Ml by the following equation:

$$
M I=\sum_{i=1}^{N}\left(\frac{N}{\phi_{19 i}\left(1-S_{W 778}\right)^{05}}\right)
$$

where ' $\mathrm{N}$ ' denotes the number of those samples with log density porosity greater than $9 \%$ and saturation of water less than $75 \%, \varphi_{n g i}$ denotes the neutron porosity of those samples having log density porosity greater than $9 \%$, and $\mathrm{S}_{\mathrm{w} 75 \mathrm{i}}$ is the saturation of water of such samples.

\subsubsection{Calibration of the seismic data}

Both conventional logs (sonic and bulk density) and check shot data (time-depth relation) of Bijnot-1 well along with seismic line were loaded into the computer program to calculate synthetic seismogram. The acoustic impedance (Al) was obtained as the product of sonic velocity $\left(V_{P}\right)$ and bulk density log, as given in Equ. (2). Using Al, the reflection coefficient (reflectivity) at each interface was then calculated by Equ. (3). In the process, we extract the wavelet from the seismic dataset, specifically seismic traces from seismic data. The wavelet extraction derived from digitized Al and bulk density logs was convolved with the series of re $\llbracket$ ectivity to compute a synthetic seismogram. The reflectivity was converted from the depth domain to the time domain using available check shot data from wells. Finally, the synthetic seismogram was then correlated with the seismic traces to build an impedance model. The Al curve closely matched with the lithofacies (e. g., high Al is related to dolomite and shale). Particularly for this dataset, we selected Ricker wavelet with a 2-millisecond sample rate, $25 \mathrm{~Hz}$ frequency, and 128-millisecond sample lengths to generate the synthetic trace. Substitution like sonic data calibration, datum, drift corrections, and seismic traces correlation was also performed during the construction of synthetic seismogram. Fig. 7 shows the synthetic seismogram, Al, relectivity series, and the computed extracted wavelet for seismic line FABS-11.

$$
\mathrm{AI}=\rho \times \mathrm{V}_{\mathrm{P}}
$$

$$
\mathrm{RC}=\frac{(\mathrm{AI})_{\text {layer }-1}-(\mathrm{AI})_{\text {layer }-2}}{(\mathrm{AI})_{\text {layer }-1}+(\mathrm{AI})_{\text {layer }-2}}
$$




\subsubsection{Seismic data inversion}

We applied a joint inversion strategy in this work that incorporates MLC and PSO algorithms to convert seismic reflection data to spatial variability in the Al and MI profiles in the Infracambrian SR formation over the studied region ${ }^{31,32}$. An open-source rock star seismic inversion software was used to predict the MI profile. Seismic line and MI data (input) were entered into the inversion software, and the parameters according to the provisions of input data were adjusted to estimate MI (output).

\section{Results And Discussion}

\subsection{Surface geochemical and geo-microbial survey}

The abundance of hydrocarbon oxidizing bacteria ranges from 0 to $525 \times 103$ (cfu/g of soil sample) (Fig. 8a). The hydrocarbon gases measured by gas chromatography show concentrations of $\mathrm{C} 2$ through C4 ranging from 0 to $900 \mathrm{ppb}$ (Fig. 8b).

Distribution maps of geo-microbial and soil gas concentrations show that the anomalies match and are well inversely correlated with each other (Fig. 8a, b). In fact, hydrocarbon micro-seeps provide suitable conditions for developing highly specialized microbial populations that consume light hydrocarbon gas as their only food source. As a result, these microbes multiply in anomalous concentrations in the nearsurface soils along with the geological structures containing hydrocarbons. Here we note that the obtained result represents the normal distribution between gas and microbial concentrations. This reverse correlation results from the consumption of the soil gas by the bacteria that oxidize hydrocarbons. The light hydrocarbons micro-seepage is consumed, particularly over the highest seepage area, allowing a high bacterial activity rate and depletion of hydrocarbon gas concentrations. The bacteria found just above the flow chimney would transform the petroleum gases, while the edges will show high gas concentration as non-utilized by bacteria where all microbial activity is prolonged.

The soil probe gas analyses show variable concentrations where $\mathrm{C} 1$ is absent, and the samples contain C2-C4 hydrocarbons. However, the amounts of migrated gases usually decrease in the order given as methane $>$ ethane $>$ propane $>$ butane. We can attribute the deficiency of methane to its total consumption by the methanotrophic bacteria in the soil. Because it is the simplest hydrocarbon molecule, methane would be the first and easiest component to decompose by bacteria causing its complete depletion in the soil gas samples in proportion to the other components.

The presence of heavier components of hydrocarbon gases, mainly propane and butane, favours a thermogenic origin of the detected gases. Nevertheless, another source of hydrocarbon gases could be detected on the surface, such as the biogenic origin.

To further investigate the origin of these surface gases, we included other studies such as geophysical characterization, including gravity modelling and seismic data interpretation, to explore if possible deep 
pathways exist, in addition to maturity estimation and biomarker analysis.

The soil probe gas concentrations are plotted and overlapped on the gravity anomaly map (also ties with seismic data interpretation and geological cross-section). The composite map of C2-C4 hydrocarbons and gravity anomaly shows a good correlation between high concentrations of C2-C4 hydrocarbons and the zone of gravity high, as well as major faults (Fig. 9). The C2-C4 hydrocarbons show high concentrations along the faults separating gravity highs and gravity lows.

The seismic lines (Fig. 6) along the surface geochemical study were also interpreted to show the structural features and possible migration pathways. The stratigraphic horizons were marked and tied using check shot velocities. The cross-sections along seismic line GG ( $n$ or th $\rightarrow$ south) and II from (east to west) were prepared and converted to depth. We note that salt-induced structural leads identified at the Infracambrian level show a continuous rise from the basement overlying stratigraphic horizons from west to east.

A geo-seismic depth section along II' lines reveals a basement high located at a distance of $40 \mathrm{~km}$ (Fig. 10a). The overlying Mesozoic-Tertiary sequence follows the rise in the basement. A four-way structural closure of $80 \mathrm{msec}(\sim 160 \mathrm{~m})$ (vertical closure) is mapped in the eastern part of the study area. A normal fault can also be observed in the seismic section. The Infracambrian top in this seismic section is identified at 1600 to $2200 \mathrm{~m}$ depth from east to the west.

A geo-seismic cross-section along with GG ${ }^{\prime}$ is oriented in the NS direction (strike line). The cross-section shows that the basement starts rising from a distance of $15 \mathrm{~km}$ to the highest crustal part located at 25 km (Fig. 10b). The Infracambrian to Tertiary strata overlying the bulge in the basement shows prominent anticlinal four-way structural closure (as shown by the dip line from east to west). The thickness of the stratigraphic horizons remains constant. The Infracambrian top in this seismic section is identified at 1400 to 1600 m depth from north to the south.

We conclude that deep-seated faults overlying the basement high as well as near-surface diffusion provided pathways for $\mathrm{C} 2-\mathrm{C} 4$ hydrocarbon migration to the surface, supporting the deep thermogenic origin of these gases. Meanwhile, this indicates the presence of an active petroleum system beneath the earth's surface.

\subsection{Burial history-maturation and hydrocarbon generation 4.2.1 vitrinite reflectance}

When modelling the burial history, we considered the regional erosional unconformity between the Cretaceous and Paleocene, the most critical erosional surfaces in the study area. In models development, we considered total erosions between 40 and $180 \mathrm{~m}$. However, after conducting a comprehensive sensitivity analysis and trying out several scenarios, we found a negligible impact of erosions on the present-day maturity and temperature trends. 
In Bijnot-1 well, a constant heat flow of approximately $72 \mathrm{~mW} / \mathrm{m}^{2}$ results in the best calibration between the measured and calculated vitrinite reflectance (Fig. 11a and 12). Burial history and thermal maturity modelling of Infracambrian rock demonstrated that Sonia, Jodhpur, Bilara, and Hanseran reached the early stages of the oil generation window, with a maximum burial temperature of approximately $105^{\circ} \mathrm{C}$ and calculated vitrinite reflectance of $0.60 \% R_{o}$ (Fig. 11a).

For the maturity profile, the Infracambrian rock (Sonia, Jodhpur, Bilara, and Hanseran Evaporite) fall within the early-stage of the oil generation window (Fig. 11b). The present-day calculated TTI is 35. Vitrinite reflectance $\left(R_{0}\right)$ in the Infracambrian source rocks encountered in the studied wells of SE Pakistan suggests immature to the early stage of oil generation window (Fig. 12).

\subsubsection{Rock-Eval pyrolysis}

The results of Rock-Eval pyrolysis of Bijnot- 1 well cuttings (Table 3 ) show TOC and HI values varying between 0.61 and $2.41 \mathrm{wt}$. \% with an average of $1.01 \mathrm{wt}$. \% and $104-451 \mathrm{mg} \mathrm{HC} / \mathrm{g} \mathrm{TOC}$ with a mean value of $209.7 \mathrm{mg} \mathrm{HC} / \mathrm{g}$ TOC respectively in the Infracambrian SR Formation. The plots of PI versus Tmax and HI versus Tmax are drawn to define the type and maturity level of the kerogen (Fig. 13). The HI versus Tmax plot reveals that more than half of the samples have reached an early mature stage of the oil window generation. A mixture of types II and III is present in SR Formation source rock with predominantly type III kerogen (Fig. 13a). This mixture with the predominance of type III explains the enrichment of the original OM in oxygenated components and, consequently, Ol's high values. In the PI versus Tmax plot, the PI values fall between 0.08 to 0.46 and Tmax from 420 to $435^{\circ} \mathrm{C}$, further confirming that Infracambrian SR Formation is thermally immature to the early-mature (stage of oil generation window) (Fig. 13b). 
Table 3

Rock-Eval pyrolysis of Bijnot-1 well cuttings from SR Formation.

\begin{tabular}{|c|c|c|c|c|c|c|c|c|c|}
\hline Sample & $\begin{array}{l}\text { Depth } \\
\text { (m) }\end{array}$ & $\begin{array}{l}\mathrm{S}_{1} \\
\text { (mgHC/g } \\
\text { Rock) }\end{array}$ & $\begin{array}{l}\mathrm{S}_{2} \\
\text { (mg } \\
\mathrm{HC} / \mathrm{g} \\
\text { Rock) }\end{array}$ & $\begin{array}{l}\mathrm{S}_{3} \\
\text { (mg } \\
\mathrm{HC} / \mathrm{g} \\
\text { Rock) }\end{array}$ & $\begin{array}{l}\mathrm{HI} \\
(\mathrm{mg} \\
\mathrm{HC} / \mathrm{g} \\
\mathrm{TOC})\end{array}$ & $\begin{array}{l}\text { Ol } \\
(\mathrm{mg} \\
\mathrm{CO}_{2} / \mathrm{g} \\
\text { TOC) }\end{array}$ & PI & $\begin{array}{l}T_{\max } \\
\left({ }^{\circ} \mathrm{C}\right)\end{array}$ & $\begin{array}{l}\text { TOC } \\
\text { (wt. } \\
\% \text { ) }\end{array}$ \\
\hline BJ-01 & 1622 & 0.73 & 1.01 & 1.32 & 127 & 165 & 0.42 & 424 & 0.81 \\
\hline BJ-02 & 1634 & 0.74 & 0.95 & 1.45 & 122 & 178 & 0.43 & 420 & 0.82 \\
\hline BJ-04 & 1642 & 0.81 & 10.55 & 2.11 & 451 & 94 & 0.08 & 425 & 2.41 \\
\hline BJ-05 & 1662 & 0.25 & 3.10 & 1.51 & 342 & 166 & 0.08 & 432 & 0.92 \\
\hline BJ-06 & 1682 & 0.22 & 0.81 & 1.36 & 203 & 338 & 0.20 & 432 & 0.61 \\
\hline BJ-08 & 1700 & 0.32 & 0.63 & 1.50 & 141 & 328 & 0.32 & 432 & 0.65 \\
\hline BJ-09 & 1742 & 0.36 & 0.42 & 1.41 & 104 & 338 & 0.44 & 433 & 0.62 \\
\hline BJ-10 & 1762 & 0.52 & 0.58 & 1.64 & 113 & 322 & 0.46 & 424 & 0.51 \\
\hline BJ-12 & 1794 & 1.41 & 2.40 & 1.90 & 212 & 170 & 0.38 & 429 & 1.32 \\
\hline
\end{tabular}

\subsection{Biomarkers results and interpretations}

\subsubsection{Source rock depositional environment}

A representative sediment whole extract gas chromatogram (WEGC) is shown in Fig. 14a. The n-alkanes distribution profile shows the higher abundance of even-carbon number n-alkanes than odd n-alkanes. This suggest a reducing environment of organic matter deposition where even-carbon n-alkanes preserved preferred to odd n-alkanes. An exclusive abundance of lower carbon range alkanes $\sim \mathrm{C}_{16}-\mathrm{C}_{20}$ in WEGC suggests marine organic matter dominance in the sediment ${ }^{24,33}$. Pristane/phytane ( $\left.\mathrm{Pr} / \mathrm{Ph}\right)$ is a good indicator of OM depositional conditions ${ }^{34}$. The obtained $\mathrm{Pr} / \mathrm{Ph}$ values are around 1 in the upper part of the analyzed interval and then decrease significantly with depth to relatively lower values $(0.40)$ at the bottom (Table 4). These values suggest a suboxic environment of deposition in the upper part, while the middle section showed an anoxic depositional condition $27,28,35$.

\subsubsection{Possible source facies}

The distribution of tricyclic terpanes, steranes, and hopanes in cuttings extracts (1742 m) was applied to determine the variation of source facies in the SR Formation (Fig. 14b, c). Hopanes are present in higher relative abundance than tricyclic terpanes. The $\mathrm{C}_{23}$ compound is the predominant peak among the tricyclic terpanes and is particularly abundant comparing to $C_{24}$ tetracyclic. The $C_{23} / C_{24}$ is about 1.5. This ratio reflects the importance of tricyclic terpanes concerning tetracyclic terpanes and is significant 
for the abundance of precursors of these compounds (tricyclohexaprenol) synthesized by bacteria as a stabilizer of microorganism membranes ${ }^{36}$. This indicates that the OM of SR Formation source rock could originate from a marine source facies enriched in microorganisms. Even so, the presence of $\mathrm{C}_{24}$ in small but significant concentrations reflects a possible minor contribution of terrestrial OM sources. Peters and Moldowan ${ }^{37}$ studied that the $\mathrm{C}_{24}$ tetracyclic terpane is related to source rocks containing continental organic matter in respectable amounts. Also, $\mathrm{C}_{20}$ and $\mathrm{C}_{21}$ are relatively abundant, and $\mathrm{C} 20$ tricyclic terpane abundance is related to terrestrial plant sources. The abundance of $\mathrm{C}_{25}$ and $\mathrm{C}_{26}$ hopanes are almost similar, with a $\mathrm{C}_{26} / \mathrm{C}_{25}$ tricyclic terpane ratios less than $0.9{ }^{36}$, indicating a prevalent marine depositional environment. Similarly, the $\mathrm{C}_{24}$ tetracyclic terpane is more abundant than the $\mathrm{C}_{26}$ tricyclic terpanes at almost all depths, revealing the marine carbonates to marl facies.

The stable $17 a(H), 18 a(H), 21 \beta(H)-28,30$-bisnorhopane were detected with low concentrations comparing to hopane ratios. This confirms that the depositional environments, in SE Pakistan, during the Infracambrian are generally suboxic. In contrast, the high $\mathrm{C}_{28}$ bisnorhopane is related to reducing physicochemical conditions in organic matter deposition environments ${ }^{38}$. In the pentacyclic terpanes, $\mathrm{C}_{29}$ and $\mathrm{C}_{30}$ hopanes content are relatively high. The $\mathrm{C}_{29} / \mathrm{C}_{30}$ hopane ratio has been used to differentiate shale and carbonate sourced oils ${ }^{37,39}$. The $\mathrm{C}_{29} / \mathrm{C}_{30}$ hopane ratios are relatively high in carbonate and evaporate sourced oils ( 0.7 or greater) and lower for shale-source oil (0.4-0.75). However, this ratio is influenced by thermal maturity. In our analysis, the $C_{29} / C_{30}$ hopane ratio varies from 0.61 to 0.84 , indicating carbonate source rock. The Gammacerane is present in low concentration proving the restriction of the deposit environment. The $\mathrm{C}_{31} \mathrm{R} / \mathrm{C}_{30}$ is generally used to distinguish between lacustrine and marine depositional environments, and sediments with a ratio of less than 0.25 are interpreted as lacustrine deposits ${ }^{36}$. The $\mathrm{C}_{31} \mathrm{R} / \mathrm{C}_{30}$ ratio of SR Formation samples shows more than 0.25 indicating a marine source facies origin.

We observe that a series of $\mathrm{C}_{27}-\mathrm{C}_{29}$ steranes are abundant in the samples, with $\mathrm{C}_{27}$ and $\mathrm{C}_{29}$ steranes predominating over $\mathrm{C}_{28}$ steranes. Also, we note that diasteranes are present in moderate to high proportions and are less abundant than regular steranes, especially for $\mathrm{C}_{27}$ diasteranes. This observation indicates a clay-starved carbonate to marl source facies in SR Formation throughout the analyzed section. The relative proportions of $\mathrm{C}_{27}$ and $\mathrm{C}_{29}$ have been proposed to indicate the origin of organic matter. The $\mathrm{C}_{29}$ and $\mathrm{C}_{27}$ steranes are thought to be derived from terrestrial and marine sources, respectively. The presence of $\mathrm{C}_{27}$ steranes in high amounts compared to $\mathrm{C}_{29}$ in SR Formation proves the marine depositional environment of the $\mathrm{OM}$, but the significant amounts of $\mathrm{C}_{29}$ steranes that are present could also bring attention to possible terrestrial contribution. The $\mathrm{C}_{30}$ steranes are present in small but significant amounts. These biomarker features indicate a marine $\mathrm{OM}$ associated with marly limestone source rock, deposited in suboxic and normal salinity depositional marine environment. The biomarker features of SR Formation showed a slight variation in source facies within the section. The upper part has comparatively more carbonate content than the lower section. A sulfur-bearing heterocyclic aromatic 
hydrocarbon, dibenzothiophene (DBT), abundance has shown an excellent source facies indicator compared with other aromatic hydrocarbons ${ }^{40}$. The DBT/phenanthrene ratios from Bijnot- 1 sediments represent up to 0.3 values indicate the significant presence of sulfur aromatics, a common phenomenon of marly source facies. These results are consistent with a deep-water marine depositional environment with restricted conditions suitable for carbonate sediments ${ }^{16,41}$.

\subsubsection{Thermal maturity}

Aliphatic and aromatic hydrocarbon parameters were applied to evaluate the thermal maturity of SR Formation sediments. Isomerization at $\mathrm{C}-22$ positions in $\mathrm{C}_{31}$ to $\mathrm{C}_{35} 17 \mathrm{a}(\mathrm{H})$-hopanes ${ }^{42}$ occurs prior to most biomarker reactions and is used for thermal maturity assessment as isomerization at $\mathrm{C}_{20}$ position in regular steranes. In response to temperature augmentation, the biologically existing $22 \mathrm{R}$ configuration transforms to $22 \mathrm{R}$ and $22 \mathrm{~S}$ mixture. As a result, the $22 \mathrm{~S} /(22 \mathrm{R}+22 \mathrm{~S})$ homohopane ratio could generally be used in determining maturity. However, homohopane isomerization attains equilibrium at the early maturity stage; therefore, $22 \mathrm{~S} /(22 \mathrm{R}+22 \mathrm{~S})$ homohopane ratio cannot be used to determine highermaturity stages ${ }^{29}$. In the analyzed $\mathrm{OM}, \mathrm{C} 32 \mathrm{~S} /(32 \mathrm{~S}+32 \mathrm{R})$ hopane values range from 0.58 to 0.65 without a significant difference in values for the analyzed section, showing that isomerization has attained equilibrium and SR Formation sediments at the early mature stage to intermediate maturity.

On the other hand, the $\mathrm{Ts} /(\mathrm{Ts}+\mathrm{Tm})$ ratio shows values around 0.35 , indicating that the $\mathrm{OM}$ has not reached the oil generation window yet, given that Ts is more stable to thermal maturity than $\mathrm{Tm}$ and the ratio $\mathrm{Ts} /(\mathrm{Ts}+\mathrm{Tm})$ increases with increasing maturity. These immature Precambrian rocks are consistent with previous studies from the basin ${ }^{35}$. However, if we examine the rest of the thermal maturity biomarkers parameters of the samples from the SR Formation, especially the deeper ones, we see a gradual increase in thermal maturity. The pregnane $\left(\mathrm{C}_{21}\right.$-sterane $)$ and methyl-pregane $\left(\mathrm{C}_{22}\right.$-sterane $)$ are also used as thermal maturity biomarkers since they are characteristic of light oils ${ }^{43,44}$. In the laboratory, these steranes are produced by thermal cracking at $300^{\circ} \mathrm{C}$ for a long period ${ }^{43}$. In the OM of the SR Formation, $\mathrm{C}_{21}$ and $\mathrm{C}_{22}$ steranes were detected in high concentrations (Fig. 14c). These pregnanes are a good indicator of relative thermal maturity (end of s.s. diagenesis-beginning of catagenesis) and alteration of OM in SE Pakistan. Aromatic hydrocarbon maturity parameters from alkylphenanthrene and alkyldibezothiophenes also support the maturity evaluation of the main stage oil generation window. Also, the results of geochemical surface exploration highlight the presence of thermogenic $C_{2}-C_{4}$ hydrocarbons, supporting the mature stage of the source rock in the subsurface.

On the whole, the biomarker features of SR Formation show a slight variation through the analyzed section. These variations in parameters most likely reflect the subtle differences in sedimentary facies, lithology, deposition environment, and conditions. The upper part has more carbonate content deposited in the marine environment under suboxic conditions $\left(C_{31} R / C_{30}\right.$ records 1.8 and 1.19 at depths $1634 \mathrm{~m}$ and $1642 \mathrm{~m}$, respectively; $\mathrm{Pr} / \mathrm{Ph}$ is near 1 and $\mathrm{Ts} /(\mathrm{Ts}+\mathrm{Tm})=0.11$ at $1634 \mathrm{~m})$, compared to the lower section which is more mature and deposited under anoxic conditions, proven from higher $\mathrm{Ts} /(\mathrm{Ts}+\mathrm{Tm})$ ratio and lower $\mathrm{Pr} / \mathrm{Ph}$ ratio, respectively. 
Table 4

Biomarker ratios from Infracambrian rock sequence of Bijnot-1, (Pr/Ph: pristane/phytane; Ts/(Ts+Tm), 18a(H)-22,29,30-trisnorneohopane/(18a(H)-22,29,30-

trisnorneohopane+17a(H)-22,29,30-trisnorhopane); $C_{32} S /(S+R), C_{32}$ Hopane, 22S/(22S+22R),

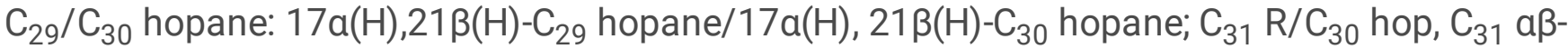
homohopane (22R)/ $\mathrm{C}_{30}$ aß-hopane).

\begin{tabular}{|llllllll|}
\hline Sample & $\begin{array}{l}\text { Depth } \\
(m)\end{array}$ & $\mathrm{Pr} / \mathrm{Ph}$ & $\mathrm{C}_{32} \mathrm{~S} /(\mathrm{S}+\mathrm{R})$ & $\mathrm{T}_{\mathbf{s}} /\left(\mathrm{T}_{\mathbf{s}}+\mathrm{T}_{\mathrm{m}}\right)$ & $\begin{array}{l}\mathrm{C}_{29} / \mathrm{C}_{30} \\
\text { hopane }\end{array}$ & $\begin{array}{l}\mathrm{C}_{31} \mathrm{R} / \mathrm{C}_{30} \\
\text { Hopane }\end{array}$ & $\begin{array}{l}\text { DBT/phe } \\
\text { nanthrene }\end{array}$ \\
\hline BJ-01 & 1622 & 1.08 & 0.63 & 0.45 & 0.76 & 0.33 & 0.13 \\
\hline BJ-02 & 1634 & 1.18 & 0.65 & 0.11 & 0.70 & 1.80 & 0.30 \\
\hline BJ-04 & 1642 & 0.93 & 0.63 & 0.39 & 0.78 & 1.19 & 0.22 \\
\hline BJ-05 & 1662 & 0.61 & 0.63 & 0.45 & 0.80 & 0.22 & 0.13 \\
\hline BJ-06 & 1682 & 1.03 & 0.58 & 0.32 & 0.61 & 0.32 & 0.14 \\
\hline BJ-08 & 1700 & 0.67 & 0.61 & 0.38 & 0.75 & 0.36 & 0.10 \\
\hline BJ-09 & 1742 & 0.80 & 0.59 & 0.44 & 0.74 & 0.29 & 0.14 \\
\hline BJ-10 & 1762 & 0.49 & 0.65 & 0.42 & 0.84 & 0.39 & 0.13 \\
\hline BJ-12 & 1794 & 0.40 & 0.58 & 0.43 & 0.70 & 0.31 & 0.18 \\
\hline
\end{tabular}

\subsection{Application of MLC and PSO algorithms for seismic data inversion}

\subsubsection{Al inversion}

Al inversion transforms seismic data into pseudo acoustic impedance logs at every trace. Fig. 15a, b shows the interpreted seismic line of FABS-11 and inverted Al using the MLC and PSO inversion strategy. It has been demonstrated that the $\mathrm{Al}$ in the zone of interest, i.e., Cambrian and Infracambrian sequence (900 to $1460 \mathrm{~ms}$ ), varies from 9000 to $13500(\mathrm{~m} / \mathrm{s}) \times(\mathrm{g} / \mathrm{cc})$. These variations of Al are associated with significant lithological changes to sandstone, shale, limestone, dolomite, and sandstone with subordinate shale lithofacies. It is to be noted that the low $\mathrm{Al}(9000-11500(\mathrm{~m} / \mathrm{s}) \times(\mathrm{g} / \mathrm{cc}))$ between time interval 1250 to $1450 \mathrm{~ms}$ indicates perhaps a potential hydrocarbon-bearing zone at this particular interval (arrow). However, the overlying red-yellow horizons just above the blue horizons (arrow) reveal higher values of $\mathrm{Al}$ $(12500-13500(\mathrm{~m} / \mathrm{s}) \times(\mathrm{g} / \mathrm{cc}))$ and is, hence, most likely an impermeable seal rock for a potential reservoir. The harder rocks, i.e., compact limestone, have higher Al than sandstone and clay ${ }^{31}$. Note that irregular patterns of low and high Al reflecting interbedded limestone and dolomite layers are wellcaptured by MLC and PSO inversion strategy (indicate with arrow) (Fig. 15b). Since a nonlinear relationship exists between the interbedded thin layers and seismic waveforms, PSO could provide a nonlinear projection correlation to determine the interbedded layers from the seismic waveform ${ }^{45}$. Good 
reservoir quality areas and thin layer beds show up clearly in the Cambrian and Infracambrian interval (arrow).

\subsubsection{Ml prediction}

$\mathrm{MI}$ is an essential parameter for determining the thermal maturity levels of hydrocarbon source rock and correlating it with thermal maturity evaluated from geochemical methods. Fig. 16 shows a graphical comparison between the calculated Ml using Equ. (1) and measured Tmax in the Infracambrian SR Formation in Bijnot-1. It is shown that the measured Tmax (red dots) falls within the early-stage of the oil generation window in the range of $420-433^{\circ} \mathrm{C}$ with $\mathrm{Ml}$ (maroon line) $2-3 \%$.

In Fig. 17, the inverted Al surface is converted into an inversion solution for a MI map using the MLC and PSO inversion strategy ${ }^{30,46}$. It is shown that the deeper horizons reveal fair to good MI values, i.e., 3 to $5 \%$ with low Al, and correspond to good reservoir quality area (arrow). It should be noted that blue and sky blue colour layers in the middle and upper part of prolle with $\mathrm{MI}<2$ correspond to the immature oil generation stage, whereas yellow and green colour layers in the lower part of prolle with $\mathrm{Ml}>4$ correspond to the early oil generation stage. The results of MI concur with the earlier research of Abdizadeh et al. ${ }^{46}$ and correlate well with the thermal maturity measured from rock-eval pyrolysis and biomarker in the studied interval. Generally, thermal maturity and MI increase as a function of depth; however, structural features such as structural highs and lows, salt-induced anticlines, and paleo highs could produce local thermal anomalies.

The comparison of original logs with inverted $\mathrm{Al}$ and $\mathrm{MI}$ from MLC and PSO for FABS-11 seismic sections is shown in Fig. 18. The plot indicates good concordance between the inverted (red line) and the computed (blue line) Al and MI. The overall correlation coefficients for both inverted and computed values are equal to 0.96 and 0.89 for $\mathrm{Al}$ and $\mathrm{Ml}$, respectively. This high correlation coefficient validates the calibration between inverted $\mathrm{Al}$ and $\mathrm{MI}$ from seismic and well log data and confirms the robustness and accuracy of the MLC and PSO inversion strategy.

\section{Research Synthesis}

The Infracambrian play in SE Pakistan has been previously explored to study the distribution and modelling of the source and reservoir rocks. Many deep wells targeting to penetrate Infracambrian rock were drilled on paleo-highs but did not encounter Infracambrian strata ${ }^{6,9}$. All wells were drilled to the uppermost column of the oil window and allowed minor in-situ heavy oil shows within the source rock beds. The timing of hydrocarbon generation versus trap formation is another reason for the failure of deep wells. The potential charging episode and maximum burial depth are likely pre-Permian, whereas the trap formation in the drilled structures is post-Permian.

The literature study from various authors revealed that the heavy oil shows from the Bijnot-1, Fort Abbas1, Karampur-1, and Marot-1 exploratory wells are remarkably similar to the Baghewala-1 oil and southern 
Oman 2,6,9,47-49. The heavy oil from Bilara and Jodhpur formations in the Baghewala-1 well and SR Formation in Karampur-1 well geochemically correlate with oil found in the eastern flank (Oman) from the carbonate-evaporite source rocks and carbonate-siliciclastic rocks connected with salt beds and anhydrite of the Infracambrian Huqf Group ${ }^{2,8,50}$. This relationship is consistent with the plate tectonic reconstruction model where, during the Late Precambrian-Early Cambrian period, marine evaporite deposits in northwest India, SE Pakistan, and southern Oman were close to each other on a large carbonate margin shelf of Gondwanaland ${ }^{1,3,4,47,51,52}$. Geochemical analysis (high proportion of $C_{29}$ steranes, monoaromatic, and diasteranes steroids, negative stable carbon isotope ratio, low pristane/phytane ratio, low diasteranes, low API gravity, and high sulfur) of Karampur-1, Baghewala-1, and southern Oman suggest similar environmental conditions with the same age, as shown in Fig. 19.

Geochemical correlations between Baghewala-1 and Karampur- 1 favor the possibility of heavy and light oil reserves in deeper buried Infracambrian source rocks in the SE flank of Pakistan extending to the BK-N Basin of India (Fig. 20).

In this regard, we investigated the potential and maturity of Infracambrian source rocks in SE Pakistan based on integrated geochemical, geological, and geophysical data from soil and core samples. Surface geochemical surveys allow rapid and low-cost preliminary identi 1 cation of hydrocarbon-bearing regions from hydrocarbon microseepages $23,53-55$. The underlying concept of surface geochemical prospecting is that faults and fractures provide pathways for light gaseous hydrocarbon migration from subsurface geological formations to the surface or shallow environment by diffusion and effusion, resulting in anomalies of surface hydrocarbon gases ${ }^{56,57}$. The surface geochemistry shows anomalous concentrations of thermogenic $\mathrm{C} 2-\mathrm{C} 4$ hydrocarbons gases in surface soils above anticlinal structures that confirm the occurrence of mature source rock in the basin as well as an active migration. The rock-eval pyrolysis and biomarkers identified marine restricted clay-starved carbonate as source rocks that have just reached the oil generation window and the mixture of types II and III kerogen. These kerogens have been expelled using several fault-controlled horsts and grabens and salt plug anticlinal structures in the overlying Infracambrian to Permian strata. The distribution of various source and reservoir rock parameters and specific biomarker parameters from Infracambrian rocks in Pakistan are correlated with Neoproterozoic-Early Cambrian successions from India and Oman Huqf oils (typined by the A1C oil) (Fig. 21). The distributions of TOC, vitrinite reflectance, and porosity are closely comparable. $\mathrm{Pr} / \mathrm{Ph}$ and $\mathrm{Ts} /(\mathrm{Ts}+\mathrm{Tm})$ distributions in Baghewala-1 and Oman Huqf oils are similar, but Infracambrian rocks in SE Pakistan have a somewhat higher abundance of $\mathrm{Pr} / \mathrm{Ph}$ and lower $\mathrm{Ts} /(\mathrm{Ts}+\mathrm{Tm})$ with a slight variation through the analyzed section. These variations in parameters most likely relect the differences in sedimentary facies, lithology, deposition conditions, and maturity. Due to localized uplift and a global eustatic fall in sea level, we can attribute these variations to the widespread Early-Middle Cambrian and the Middle/Upper Permian unconformity in the study area. The upper part of the SR Formation is sometimes absent due to erosion during the Cambrian and Permian unconformity, which could explain why the upper part is more oxygenated. It is uplifted and, as a result, more exposed. This exposure makes 
the $\mathrm{OM}$ in the upper part subject to alteration and explains the immature biomarkers features we detected in some samples and the possible minor terrestrial provision recorded.

\section{Conclusions}

We document the evaluation of source parameters from Neoproterozoic rocks (Infracambrian rock sequence) in SE Pakistan and adjacent BK-N Basin India, using geophysical data, cores, rock-eval pyrolysis, biomarker, and surface geochemical samples. Based on available data and techniques, we can draw the following conclusions:

1. The seismic and well log data interpretation identified the Infracambrian rock sequence at 1600 to 2200 meters (east to west) with promising structural features. The structural interpretation of geoseismic cross-sections and gravity anomaly maps show several fault-controlled horsts and grabens and salt plug anticlinal structures in the overlying Infracambrian to Permian strata.

2. From the investigated surface geochemical samples, anomalous concentrations of thermogenic $\mathrm{C2}$ C4 hydrocarbons in surface soils above anticlinal structures confirmed the presence of a mature source rock capable of generating and expelling hydrocarbons. An effective migration is conveying those hydrocarbons along deep-seated faults to the surface.

3. The investigated core samples from the Infracambrian rock sequence using rock-eval pyrolysis and biomarkers show that deeper buried source rocks in the SE flank of Pakistan have marine restricted clay devoid carbonate to marl source facies with thermal maturity in the early-stage of oil generation window and a mixture of types II and III kerogen.

4. The good correlation of thermal maturity deduced from the inverted MI profile with the results of the surface geochemical survey, source biomarkers, and Rock-Eval pyrolysis proved the reliability of the proposed MLC and PSO algorithms. The spatial variations of the inverted MI profile show a reasonable estimation of thermal maturity for identifying the prospective areas and migration routes in the SR Formation.

5. The integration of surface geochemical survey, source biomarkers, Rock-Eval pyrolysis, and geophysical characterization suggests that significant heavy and light oil reserves could be explored along the SE flank of Pakistan where the Infracambrian rock sequence is thicker, thermally mature compared to the BK-N Basin, India, as well as the existence of deep-seated structural closure. However, estimating those potential reserves still needs more profound geophysical studies to validate the structural traps and related petroleum systems.

\section{Declarations}

\section{Acknowledgments}

The Shandong Provincial Natural Science Foundation provided financial support for this research (No. ZR2019BD063). 


\section{Conflict of Interest}

The authors state that they are not involved in any conflicts of interest.

\section{Author Contributions}

Conceptualization, Q. Yasin and G. Xufei; Methodology, Q. Yasin; Formal analysis, S. Baklouti and GMD Sohail; Investigation, Q. Yasin and G. Xufei; Resources, Q. Yasin and G. Xufei; Data curation, GMD Sohail; Writing-original draft preparation, Q. Yasin; Writing-review and editing, M. Asif and GMD Sohail; Visualization, M. Asif; Supervision, G. Xufei. All authors have read and agreed to the published version of the manuscript.

\section{References}

1 Matte, B. W., Conway, M. S. . Carbonate/evaporite deposition in the Late Precambrian-Early Cambrian Ara Formation of southern Oman. Special Publication London, 617-636 (1990).

2 Peters, K. E., Clark, M. E., Gupta, U. D., McCaffrey, M. A., Lee, C. Y. . Recognition of an Infracambrian Source Rock based on Biomarkers in the Baghewala-1 Oil, India. AAPG Bulletin79, 1481-1494 (1995).

3 Schröder, S., Schreiber, C., Amthor, J.E., Matter, A. . A depositional model for the terminal NeoproterozoicEarly Cambrian Ara Group evaporites in south Oman. Sedimentology50, 879-898 (2003).

4 Schröder, S., Grotzinger, J.P., Amthor, J.E., Matter, A. . Carbonate deposition and hydrocarbon reservoir development at the Precambrian-Cambrian boundary: The Ara Group in South Oman. Sedimentary Geology180, 1-28 (2005).

5 Singh, A. K., Tewari, P.K. . Infracambrian Hydrocarbon Systems and Emerging Hydrocarbon Potential in Bikaner-Nagaur and Jaisalmer Basins (Miajlar Subbasin), Rajasthan, India. 2nd South Asian Geoscience Conference, Greater Noida, New Delhi, IndiaSearch and Discovery Article \#10324 (2011).

6 Riaz A. S., J., M. A., McCann, J., Saqi, M. I. . Distribution of Infracambrian reservoir in Punjab Platform. Annual Technical Conference (ATC), Islamabad, Pakistan (2003).

7 Rajagopalan, S., Santaram, T.V., Guha, J., Pavithran, D. . Early Work Indicates Prospectivity in BikanerNagaur basin, India. Oil and Gas Journal (2002).

8 Raju, S. V., Mathur, N., Sarmah, M.K. . Geochemical characterization of Neoproterozoic heavy oil from Rajasthan, India: implications for future exploration of hydrocarbons. Current Science107 1298-1305 (2014).

9 Jamil, A., Sheikh, R. A. An overview of Neoproterozoic reservoirs in Pakistan. Geological Society London Special Publications366, 111-121, doi:10.1144/SP366.2 (2012). 
10 Hasany, S. T., Aftab, M., Siddiqui, R. A. Refound Exploration Opportunities in Infracambrian and Cambrian Sediments of Punjab Platform, Pakistan. SPE/PAPG Annual Technical Conference Islamabad, Pakistan (2007).

11 Siddiqui, N. K. A prospective Neoproterozoic-Cambrian hydrocarbon/exploration play in the Kirthar Fold Belt, Pakistan. Geological Society London Special Publications, doi:10.1144/SP366.13 (2012).

12 Adil, N., Sohail, G. 3D geological modeling of Punjab platform, Middle Indus Basin Pakistan through integration of Wireline logs and seismic data. Journal of the Geologica/ Society of India83, 211-217 (2014).

13 Kazmi, A. H., Jan, M. . Geology and Tectonic of Pakistan. Graphic Publishers Karachi, Pakistan (1997).

14 Kazmi, A. H., Abbasi, I.A. . Stratigraphy and Historical Geology of Pakistan. Department and National center of Excellence in Geology, Peshawar(2008).

15 Cozzi, A., Rea, G., Craig, J. . From global geology to hydrocarbon exploration: Ediacaran-Early Cambrian petroleum plays of India, Pakistan and Oman. Geological Society London, 131-162 (2012).

16 Craig, J., Hakhoo, N., Bhat, G.M., Hafiz, M. . Petroleum systems and hydrocarbon potential of the NorthWest Himalaya of India and Pakistan. Earth-Science Reviews187, 109-185 (2018).

17 Pareek, H. S. Pre-Quarternary geology and mineral resources of northern Rajasthan. Mem. Geol. Surv. India115, 1-41 (1984).

18 Khalid, P., Yasin, Q. . Integrating Core and Wireline Log Data to Evaluate Porosity of Jurassic Formations of Injra-1 and Nuryal-2Wells, Western Potwar, Pakistan. Journal Geological Society of India86, 553-562 (2015).

19 Craig, J., Thurow, J., Thusu, B., Whitham, A., Abutarruma, Y. Global Neoproterozoic petroleum systems: the emerging potential in North Africa. The Emerging Potential in North Africa326, 1-25 (2009).

20 Gupta, D. U., Bulgauda, S.S. . An overview of the geology and hydrocarbon occurrences in the western part of Bikaner-Nagaur Basin. Journal of Petroleum Geology3, 1-17 (1994).

21 Khalid, P., Furrukh, Q., Yasin, Q. . Data driven sequence stratigraphy of the cretaceous depositional system, Punjab Platform, Pakistan. Surveys in Geophysics35, 1065-1088 (2014).

22 Tedesco, S. A. Surface Geochemistry in Petroleum Exploration. Chapman \& Hall Inc. New York, 206 (1995).

23 Baklouti, S., Ahmadi, R., Bougi, M. S., Rasheed, M. A., Srinivasa, P.L., Hasan, S., Ksibi, M. Surface geochemical prospection for hydrocarbons in the oriental platform; the case of Guebiba oilfield, Sfax region, Tunisia. Journal of Petroleum Science and Engineering159, 830-840 (2017). 
24 Tissot, B. P., Welte, D.H. . Petroleum Formation and Occurrence. Springer New Yorksecond ed. , 699 (1984).

25 Waples, D. W. Geochemistry in Petroleum Exploration. Boston, Inter. Human Resources and Develop. Co., 232 (1985).

26 Peters, K. E., Cassa, M. R. . Applied source rock geochemistry. American Association of Petroleum Geologists Memoir, 93-120 (1994).

27 Asif, M., Fazeelat, T., Grice, K. . Petroleum geochemistry of the Potwar Basin, Pakistan: Oil-oil correlation using biomarkers, $\delta 13$ C and SD. Organic Geochemistry42, 1226-1240 (2011).

28 Asif, M., Fazeelat, T. . Petroleum geochemistry of the Potwar Basin, Pakistan: Il- Oil classification based on heterocyclic and polycyclic aromatic hydrocarbons. Applied Geochemistry27, 1655-1665 (2012).

29 Hoş-Çebi F., K., S. . Organic Geochemistry of Ağaçbası Yayla Peat Deposits, Köprübaşı/Trabzon, NE Turkey. International Journal of Coal Geology146, 155-165, doi:https://doi.org/10.1016/j.coal.2015.05.007 (2015).

30 Zhao, H., Natalie, B.G., Brad, C. . Thermal maturity of the Barnett Shale determined from well-log analysis. AAPG Bulletin 91, 535-549 (2007).

31 Yasin, Q., Yan D., Ismail, A., Du, Q. . Estimation of petrophysical parameters from seismic inversion by combining particle swarm optimization and multilayer linear calculator. Natural Resources Research, doi:https://doi.org/10.1007/s11053-020-09641-3 (2020).

32 Ding, Y., Cui, M., Zhao, F., Yasin, Q. A Novel Neural Network for Seismic Anisotropy and Fracture Porosity Measurements in Carbonate Reservoirs. Arab. .J Sci. Eng., doi:https://doi.org/10.1007/s13369021-05970-4 (2021).

33 Hoş-Çebi, F. Organic geochemical characteristics and paleoclimate conditions of the Miocene coals at the Çan-Durali (Çanakkale). Journal of African Earth Sciences, 117-135, doi:10.1016/j.jafrearsci.2016.12.003 (2017).

34 Hoş-Çebi, F., Korkmaz, S. . Organic geochemistry and depositional environments of Eocene coals in northern Anatolia, Turkey. Fue/113, 481-496, doi:10.1016/j.fuel.2013.05.086 (2013).

35 Asif, M., Iqbal, M. A. . Geochemical significance of Cambrian organic matter from Salt Range of Potwar Basin, Pakistan. Petroleum Science and Technology32, 2625-2634 (2014).

36 Peters, K. E., Walters, C.C., Moldowan, J. M. . The Biomarker Guide. Cambridge University Presssecond edition (2005). 
37 Peters, K. E., Moldowan, J. M. . The Biomarker Guide, Interpreting molecular fossils in petroleum and ancient sediments. Prentice-Hall, Englewood Cliffs NJ (1993).

38 Mello, M. R., Telnæs, N., Gaglianone, P. C., Chicarelli, M. I., Brassell, S. C., Maxwell, J. R. . Organic geochemical characterization of depositional palaeoenvironments of source rocks and oils in Brazilian marginal basins. Advances in Organic GeochemistryPergamon Press Oxford, 31-45 (1988).

39 Connan, J. Biodegradation of crude oils in reservoirs. In: Brooks, J., Welte, D. H. (Ed.), Advances in Petroleum Geochemistry, 1. Academic Press London, 299-335 (1984).

40 Asif, M., Grice, K., Fazeelat, T. . Assessment of petroleum biodegradation using stable hydrogen isotopes of individual saturated hydrocarbons and polycyclic aromatic hydrocarbon distributions in oils from the Upper Indus Basin, Pakistan. Organic Geochemistry40, 301-311 (2009).

41 Ahmad, W., Alam, S. Organic Geochemistry and Source Rock Characteristics of Salt Range Formation, Potwar Basin, Pakistan. Pakistan Journal of Hydrocarbon Research17, 37-59 (2007).

42 Ensminger, A., Albrecht, P., Ourisson, G., Tissot, B. . Evolution of polycyclic alkanes under the effect of burial (Early Toarcian Shales, Paris Basin). Advances in Organic Geochemistry 45-52 (1977).

43 Wingert, W. S., Pomerantz, M. . Structure and significance of some twentyone and twenty-two carbon petroleum steranes. Geochimica et Cosmochimica Acta50, 2763-2769 (1986).

44 Suzuki, N., Sakata, S., Kaneko, N. . Biomarker Maturation. Levels and primary migration stage of Neogene Tertiarycrude oils and condensates in the Niigata sedimentary basin. Journal of the Japanese Association for Petroleum Technology52, 499 - 510 (1987).

45 Sohail, G. M., Hawkes, C.D., Yasin, Q. . An Integrated Petrophysical and Geomechanical Characterization of Sembar Shale in the Lower Indus Basin, Pakistan, Using Well logs and Seismic Data. Journal of Natural Gas Science \& Engineering, doi:https://doi.org/10.1016/j.jngse.2020.103327 (2020).

46 Abdizadeh, H. A., Ahmadi, K. A., Heidarifard, M., Shayest, M. . Estimation of thermal maturity from well logs and seismic data in the Mansuri oilfield, SW Iran. Journal of Petroleum Science and Engineering159, 461-473 (2017).

47 Teichert, C. Continental facies of Cambrian and Gondwana Age, Salt Range, Pakistan International Geology Congress Abstract (1976).

48 Marjeby Al, A. A., Nash, D. F. . A summary of the Geology and Oil Habitat of the Eastern Flank Hydrocarbon Province of South Oman. Marine and Petroleum Geology (1984).

49 Gorin, G. E., Ratez, L. G., Walter, M. R. . Late-Precambrian-Cambrian sediments of the Huqf Group Sultanate of Oman. AAPG Bulletin (1982). 
50 Gee, E. R. Overview of the geology and structure of the Salt Range, with observations on related areas of northern Pakistan. Geological Society of America Special Paper232, 95-112 (1989).

51 Husseini, M. I., Husseini, S. I. . Origin of the Infracambrian Salt Basins of the Middle East. Geological society Special Publication50 (1990).

52 Amthor, J. E., Ramseyer, K., Faulkner, T., Lucas, P. Stratigraphy and sedimentology of a chert reservoir at the Precambrian-Cambrian boundary: the Al Shomou silicilyte, south Oman salt basin. Geo Arabia10, 89-121 (2005).

53 Jones, V. T., Matthews, M.D., Richers, D. M. Light hydrocarbons for petroleum and gas prospecting. Handbook of Exploration Geochemistry 7, 133-212 (2000).

54 Zhang, L., Bai, G. Zhao, K. Sun, C. . Restudy of acid-extractable hydrocarbon data from surface geochemical survey in the Yimeng Uplift of the Ordos Basin, China: improvement of geochemical prospecting for hydrocarbons. Mar. Pet. Geol.23, 529-542 (2006).

55 Sechman, H., Dzieniewicz, M., Liszka, B. . Soil gas composition above gas deposits and perspective structures of the Carpathian foredeep. Applied Geochemistry27, 197-210 (2012).

56 Schumacher, D., Abrams, M.A. . Hydrocarbon migration and its near surface expression. Am. Assoc. Pet. Geol. Mem.66, 446 (1996).

57 Mani, D., Kumar, T. S., Rasheed, M. A., Patil, D. J., Dayal, A. M., Rao, T.G. Balaram, V. . Soil iodine determination in deccan syneclise, India: implications for near surface geochemical hydrocarbon prospecting. Natural Resources Research 20, 75-88 (2011).

\section{Figures}

\section{Figure 1}

(a) Tectonic map of Pakistan indicating structural features and locations of the study area, (b) map showing wells located in the SE Pakistan and the BK-N from India. The igneous rocks (Aravalli Range) are exposed in the BK-N Basin 2,17. 


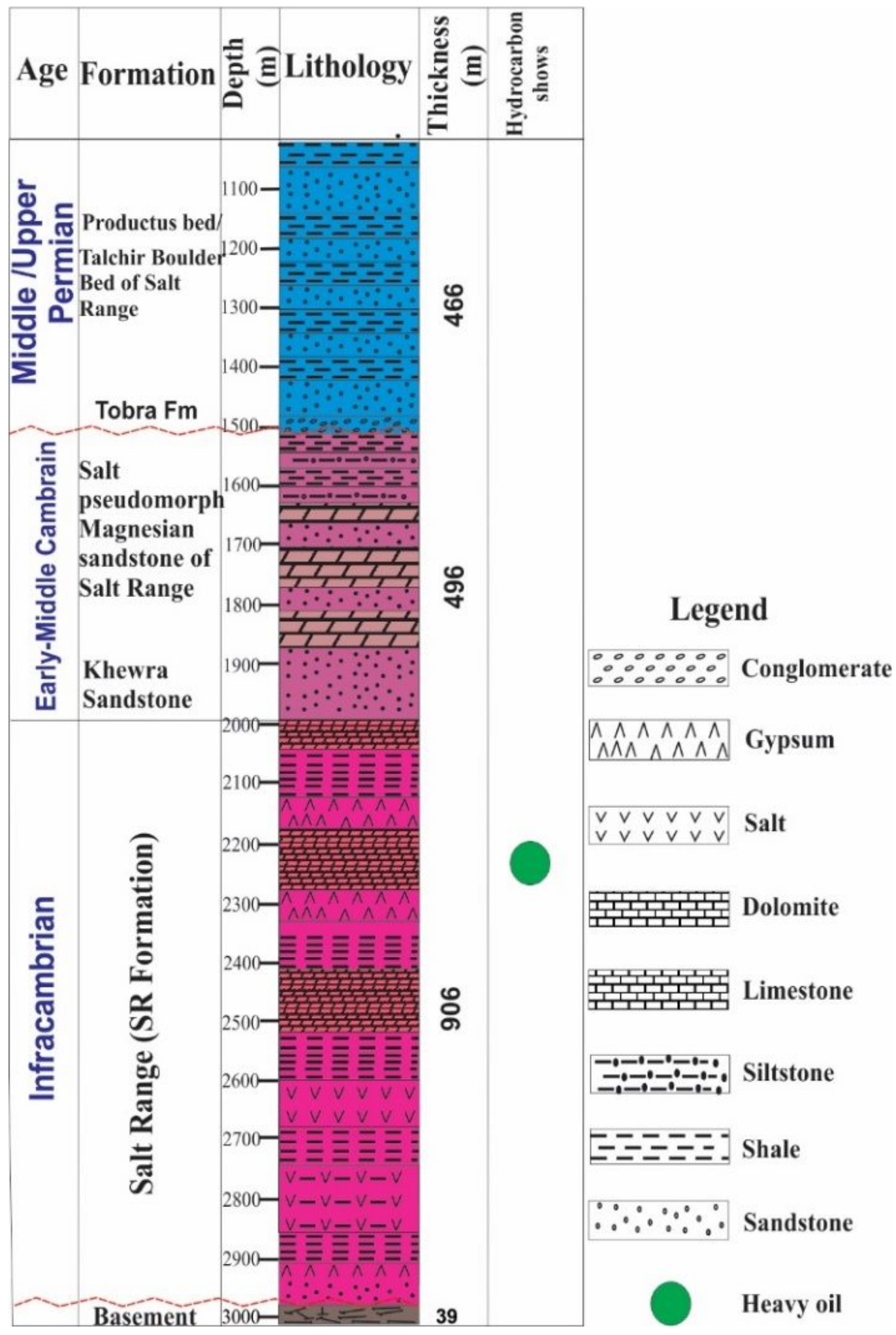

Figure 2

Generalized stratigraphic column of the Karampur-1 well, SE Pakistan. 


\section{CAMBRIAN-INFRACAMBRIAN}

\begin{tabular}{|c|c|c|c|c|c|c|c|c|}
\hline \multirow{2}{*}{\multicolumn{2}{|c|}{ Age }} & \multirow{2}{*}{\multicolumn{2}{|c|}{ Formation }} & \multirow{2}{*}{ DESCRIPTION } & \multicolumn{3}{|c|}{ Petroleum System } & \multirow{2}{*}{ Lithology } \\
\hline & & & & & Source & Reservoit & Seal & \\
\hline \multirow{10}{*}{ 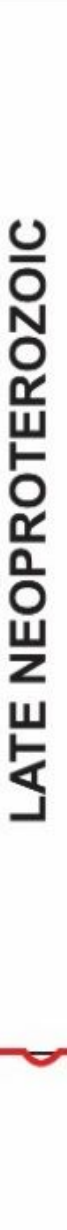 } & \multirow{4}{*}{ 孞 } & \multicolumn{2}{|c|}{ BAGHANWALA } & Shale and sandstone & & & & 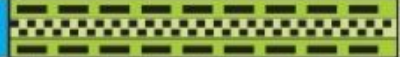 \\
\hline & & \multicolumn{2}{|c|}{ JUTANA } & Dolomite, limestone & & & & \\
\hline & & \multicolumn{2}{|r|}{ KUSSAK } & Sandstone & & & & \\
\hline & & \multicolumn{2}{|c|}{$\begin{array}{l}\text { KHEWRA } \\
\text { (NAGAUR) }\end{array}$} & $\begin{array}{l}\text { Sandstone, shale, gypsum, } \\
\text { halite and limestone }\end{array}$ & & & & \begin{tabular}{|l|l|} 
\\
$\ldots \ldots \ldots \ldots$
\end{tabular} \\
\hline & \multirow{6}{*}{ 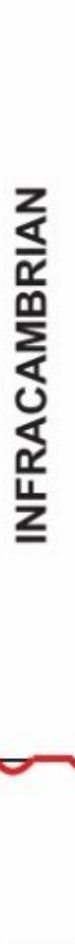 } & & HANSERAN & Evaporites, halite and shale & & & & - \\
\hline & & \multirow{4}{*}{ 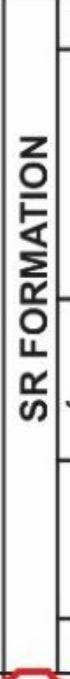 } & POKRAN & Boulders, Conglomerate & & & & \\
\hline & & & BILARA & $\begin{array}{l}\text { Chert, cherty dolomite, limestone, } \\
\text { cherty and ferruginous breccia }\end{array}$ & & & & 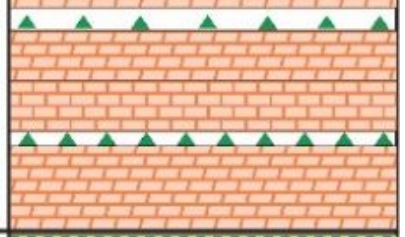 \\
\hline & & & JODHPUR & Sandstone & & & & $\begin{array}{l}\alpha \\
\alpha\end{array}$ \\
\hline & & & SONIA & Shale and sandstone & & & & 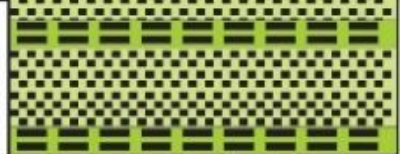 \\
\hline & & & $\begin{array}{l}\text { BASEMENT } \\
\text { (MALANI) }\end{array}$ & $\begin{array}{l}\text { Boulders and conglomerate } \\
\text { Malani volcanics, erinpura granite, } \\
\text { archean basement }\end{array}$ & & & & 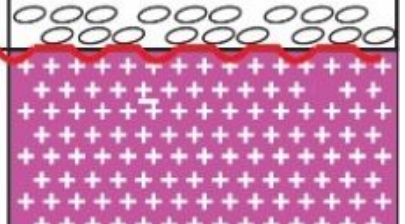 \\
\hline
\end{tabular}

Figure 3

Stratigraphic column and petroleum system of the Cambrian-Infracambrian SR Formation in the SE Pakistan and BK-N Basin. 


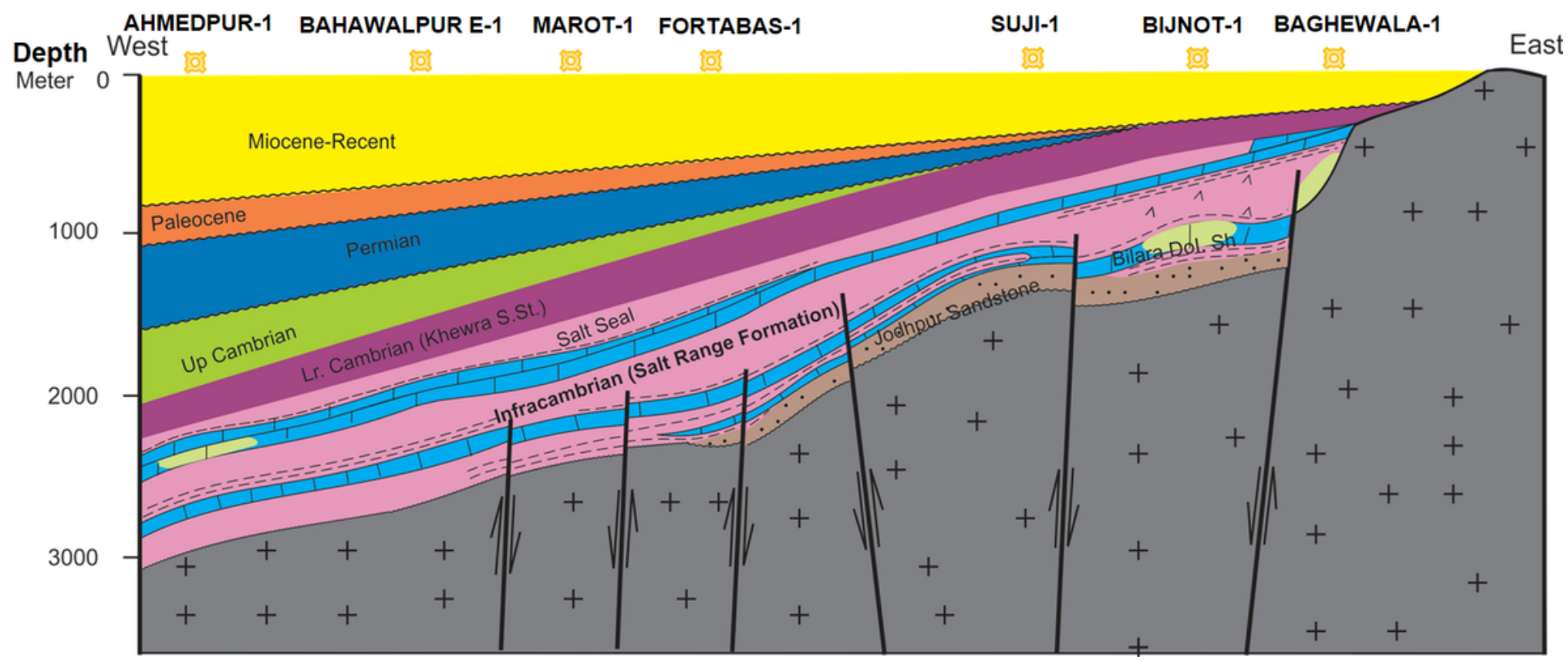

Figure 4

Regional schematic stratigraphic cross-section and structural interpretation along with the SE Pakistan and part of BK-N Basin India. The strata are dipping westward.

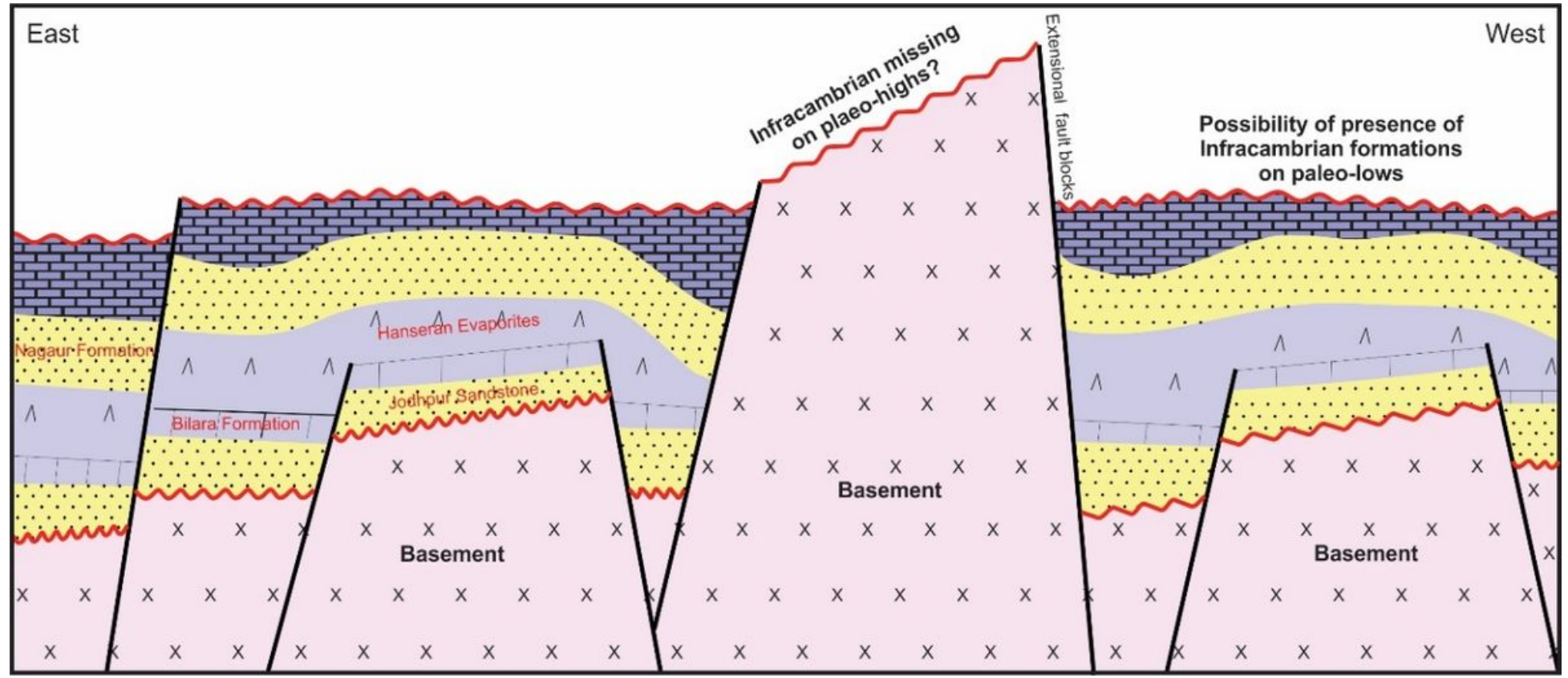

Figure 5

Conceptual play type of Infracambrian rock sequence in BK-N Basin India 6,9.

Figure 6 
The location of sampling sites along with the seismic and gravity profiles (blue lines show seismic crosssection) over the study area.

\section{Figure 7}

Synthetic seismogram (red traces) for Bijnot-1 well, showing from left to right: true vertical depth in meter, sonic velocity $(\mu \mathrm{s} / \mathrm{ft})$ and bulk density $(\mathrm{g} / \mathrm{cm} 3)$ logs, reflectivity (reflection coefficient), acoustic impedance (AI), lithology, synthetic seismogram, traces from a part of seismic line FABS-11, and two-way time in $\mathrm{ms}$.

\section{Figure 8}

(a) Distribution plot of microbial values anomalies, (b) distribution plot of soil probe C2-C4 hydrocarbons. 


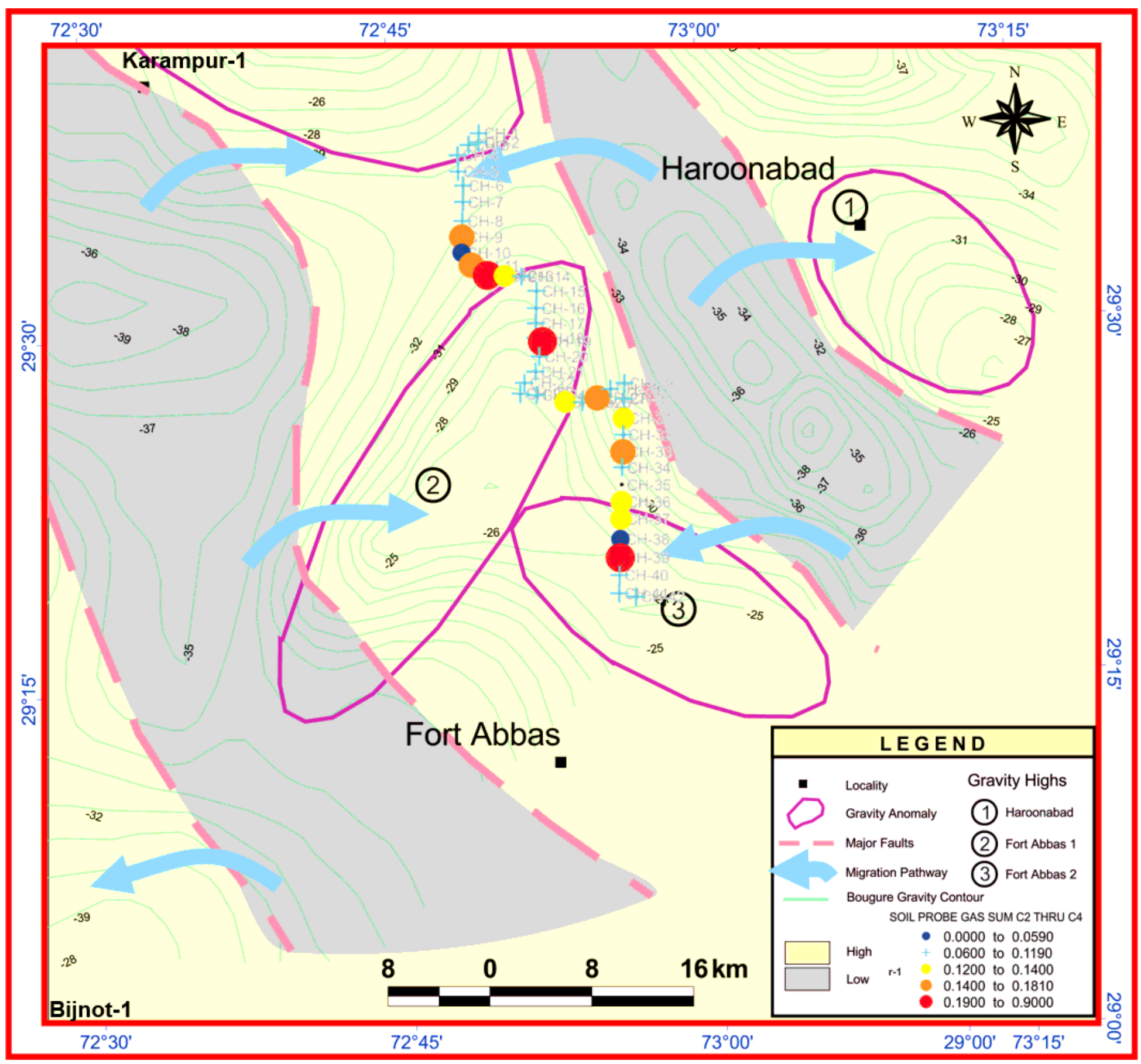

Figure 9

The overlapping of C2-C4 hydrocarbons anomalies on the interpreted gravity anomaly map. The location of gravity profiles is shown in figure 6 .

\section{Figure 10}

Seismic converted depth section indicating seepage through the main faults (shown with blue arrow), (a) along the cross-section II, (b) alongthecross - sectionGG. 

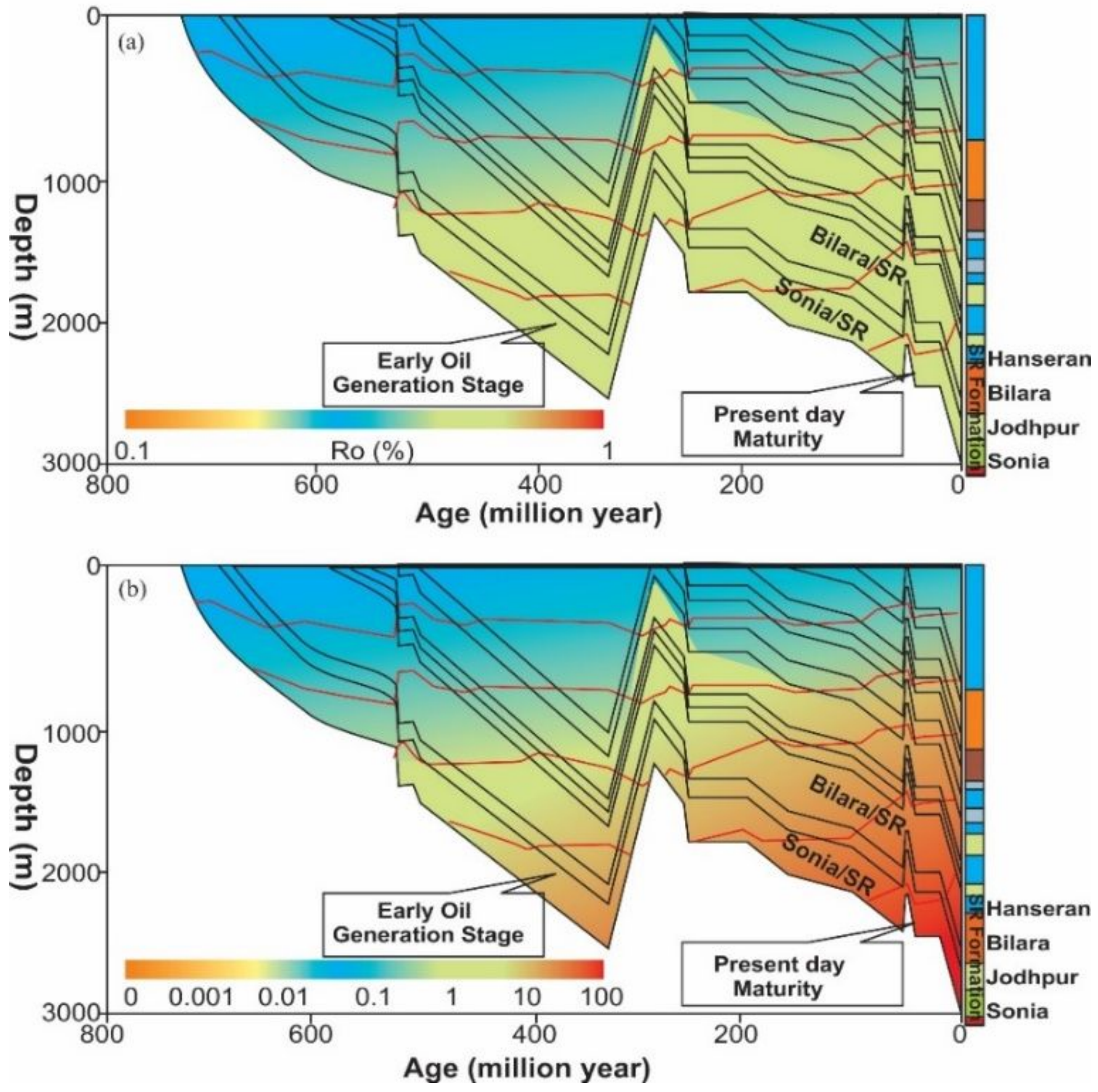

Figure 11

Burial history and thermal modelling of Infracambrian rock, (a) vitrinite reflectance, (b) maturity profile.

Figure 12 
A plot of vitrinite reflectance calculation in the Karampur-1, Bijnot-1, and Bahawalpur E-1 wells of SE Pakistan.

\section{Figure 13}

Thermal maturation assessment of Infracambrian SR Formation, (a) plot of HI versus Tmax, (b) plot of PI versus Tmax.

\section{Figure 14}

(a) Whole extract gas chromatogram of Bijnot-1 sediment (1742 m) show n-alkane and isoprenoids distribution, (b) selected ion chromatogram (191) shows the distribution of tricyclic and pentacyclic (Hopanes) terpanes in a representative sample from Bijnot-1. Letters with $\mathrm{T}$ and $\mathrm{H}$ refers to tricylic terpanes and hopanes, respectively, number on peaks represent the carbon numbers of the respective compound, 24TeT; 24 tetracyclic terpane, (c) selected ion chromatogram (217) shows the distribution of steranes and diasteranes, numbers on peaks represent the carbon numbers of steranes and diasteranes.

\section{Figure 15}

(a) Interpreted seismic line of FABS-11, (b) the relative inverted acoustic impedance using MLC and PSO inversion strategy.

\section{Figure 16}

Graphical comparison between calculated maturity index (MI) and Tmax in Bijnot-1 (red dots represent Tmax and maroon line for MI).

\section{Figure 17}

Seismic inverted MI profile using the MLC and PSO inversion strategy in Cambrian and Infracambrian rock sequence at $1100-1500 \mathrm{~ms}$.

\section{Figure 18}

Plots comparing the original logs (blue) and inverted results (red) in Bijnot-1 well, (a) acoustic impedance, and (b) maturity index (MI). 


\section{Figure 19}

The analysis of the geochemistry of hydrocarbons (oil) in southern Oman' Huqf' and 'Q' oil, Karampur-1 (Pakistan), and Baghewala-1 (India) (modified after Craig et al. 16).

\section{Figure 20}

Subsurface correlation of Neoproterozoic sequence (Nagaur, Hanseran, Bilara, and Jodhpur Formations) in the SE Pakistan and BK-N Basin India.

\section{Figure 21}

Distribution of various source and reservoir rock properties along with certain biomarkers parameters in Infracambrian rock sequence from SE Pakistan, India, and southern Oman. 